\title{
Distribution of Trifolium rubens in Ukraine and the current state of its populations in Zakarpattia
}

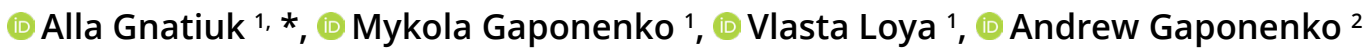 \\ 1 M.M. Gryshko National Botanical Garden, National Academy of Sciences of Ukraine, Tymiryazevska str. 1, 01014 Kyiv, Ukraine; \\ gnatiukalla@gmail.com \\ ${ }^{2}$ National University of Life and Environmental Sciences of Ukraine, Heroiv Oborony str. 15, build. 4, 03041 Kyiv, Ukraine
}

Received: 13.11.2020 | Accepted: 09.04.2021 | Published online: 28.04.2021

\begin{abstract}
Trifolium rubens is a Central European forest-steppe plant species reaching its eastern distribution limit in Ukraine and listed in the Red Book of Ukraine (2009).

Our study was carried out in 2016-2020 and aimed to analyze the distribution of $T$. rubens in Ukraine, to identify the composition of phytocoenoses with T. rubens, and to evaluate the current state of its populations in the Zakarpattia region of Ukraine. The distribution of this species was analyzed based on data obtained from the field surveys, literature, online resources, and herbaria. In total, 78 localities of $T$. rubens were analyzed. Trifolium rubens was found to be distributed in Zakarpattia, Lviv, Ivano-Frankivsk, Ternopil, Rivne, Khmelnytskyi, Chernivtsi, and Vinnytsia regions of Ukraine. Two of these regions (Khmelnytskyi and Chernivtsi) were not mentioned before in the Red Book of Ukraine. The presence of T. rubens in Volyn, Zhytomyr, Cherkasy, and Kyiv regions is doubtful and not confirmed by recent data. Most localities of this species are known from Zakarpattia and Lviv regions.

Three new localities were found in the Beregovo district of the Zakarpattia region in the foothills of the Volcanic Carpathians. The floristic compositions of the plant communities and ontogenetic structure of T. rubens populations in Beregovo and Mukachevo districts of the Zakarpattia region were investigated. Investigated populations are isolated with a dispersed disposition of plants on large areas. Trifolium rubens occurs here in meadow-steppe and meadow areas, on hillsides, and also participate in mesoxerophilous secondary (semi-natural) shrub communities in anthropogenically transformed areas. Often such populations are situated along pathways, on forest edges and fallow lands, and associated with ecotones of Trifolio-Geranietea sanguinei class. All studied populations were incomplete with the domination of generative shoots.
\end{abstract}

Keywords: Trifolium rubens, chorology, populations, Ukraine

Authors' contributions: Gnatiuk A. and Gaponenko M. conceived the investigation and its main conceptual ideas, designed the study, and analyzed the data. Loya V. and Gnatiuk A. collected the data from the herbaria, and made a map. Gnatiuk A., Gaponenko M., Loya V., and Gaponenko A. realized the field research, collected data, took photos, collected herbarium, identified plant samples, composed species lists, and realized a final approval of the manuscript. Gnatiuk A., Gaponenko M., and Loya V. wrote the manuscript and worked on its critical revisions.

Funding: The work has been conducted within the research program of the M.M. Gryshko National Botanical Garden № 387-PH "Development of scientific bases for conservation, enrichment and efficient use of resources of valuable introducers and rare plants under the influence of climate change in Ukraine" (state registration number 0117U000816) and at the authors' own expense.

Competing Interests: The authors declared no conflict of interest. 


\section{Introduction}

Trifolium rubens L. is a Central European forest-steppe plant species. It is also present in Southern Europe, including southern Spain, Italy, and Eastern Europe. Some species' findings were reported from Belarus (Meusel \& Jäger, 1992). Also, a few localities are known from the Baltic region (Rašomavičius, 2007) and the south of Thrace (Meusel \& Jäger, 1992).

In Ukraine, T. rubens is a rare species (Didukh, 2009), reaching its eastern distribution limits. It is mostly distributed in the right-bank part of Ukraine, where it occurs on dry meadows, meadow-steppes, forest edges, and growths among shrubs. Didukh (2009) indicated that T. rubens occurs in Zakarpattia and Volyno-Podilia of Ukraine only. However, the preliminary chorological research showed that it probably has a broader distribution range.

In Ukraine, T. rubens mainly participates in the plant communities Festuco-Brometea Br.Bl. et Tx. ex Soó 1947, Molinio-Arrhenatheretea Tx. 1937, and Trifolio-Geranietea sanguinei T. Müller 1961. It is also a diagnostic species for association Primulo veris-Agrostietum capillaris Uhliarová et Janišová 2014. Beside this, T. rubens participates in the thermophilic communities of ecotones, forest edges, and shrubby association Antherico ramosiGeranietalia sanguinei Julve 1993 (Didukh, 2009; Dubyna et al., 2019).

In the adjacent countries, T. rubens is associated with some more communities. For example, in Poland it is listed for the order Quercetalia pubescentis Br.-Bl. (1931) 1932 (Matuszkiewicz, 2001). Trifolium rubens is also mentioned as an indicator of thermophilic Trifolio-Geranietea communities in Slovakia (Ružičková et al., 1996).

Usually, the populations of $\mathrm{T}$. rubens in Ukraine are small, with sporadically distributed or joined in small groups (from a few individuals to several dozens) plants. These populations are mainly situated on the slopes of the southern and south-eastern exposures (Ralo, 2002; Onyshchenko \& Andrienko 2012; Dmytrash, 2015; Dmytrash-Vatseba \& Shumska, 2016; Konishchuk et al., 2017).

This study was aimed to clarify the distribution of $T$. rubens in Ukraine and its participation in plant communities. It also aimed to evaluate the current state of
T. rubens populations in the Zakarpattia region of Ukraine.

\section{Material and methods}

The study was carried out in 2016-2020. Trifolium rubens distribution analysis was based on the data from the field surveys, literature, Internet resources, and examination of the herbarium vouchers from UU, KW, LWS, KWHA, CHER, MW, MNR, MSUD, UPU, SOF, UM, KWHU, KWU (see Thiers (2016) for acronyms), and KW-museum (herbarium of the National Museum of Natural History of the NAS of Ukraine, Kyiv).

Populations were studied in the Zakarpattia region in June (flowering period) and August (fruiting period). In particular, the populations in the low mountain range of the Beregovo volcanic hills and on the mountain Lovachka were investigated in the following localities: 1) Beregovo; 2) Zatyshne 3) Muzhievo, and 4) Mukachevo (Figs. $1 \& 2$ ).

Trifolium rubens is a herbaceous perennial polycarpic. Shoot system of T. rubens is represented by elongated monocyclic shoots. The degree of development and number of shoots reflect individuals' state and prospects of seed reproduction in the population. Establishing the real age structure of T. rubens populations in natural habitats, as in some other perennial species, is difficult. It is impossible to do this without damaging plants and soil surface, especially in dense communities. Such damage is unacceptable for studying rare plant species. In this case, a ratio of the number of generative and vegetative shoots may be a key for population monitoring (Kagalo et al., 2012). Hence, in each locus, the shoots of four age stages: virginal, generative, subsenile, and senile (Gnatiuk et al., 2020), were registered and investigated.

In each population, the vegetation composition was evaluated following BraunBlaquet (1964). The scientific names of the plants are provided according to POWO (2021), the names of the vegetation communities - according to Dubyna et al. (2019) and Solomakha (2008).

\section{Revised specimens}

Vinnytsia region. Nemyriv district: Antsipolivka, 08.06.2009, Vashenyak (KW), (Didukh et al., 2010). 

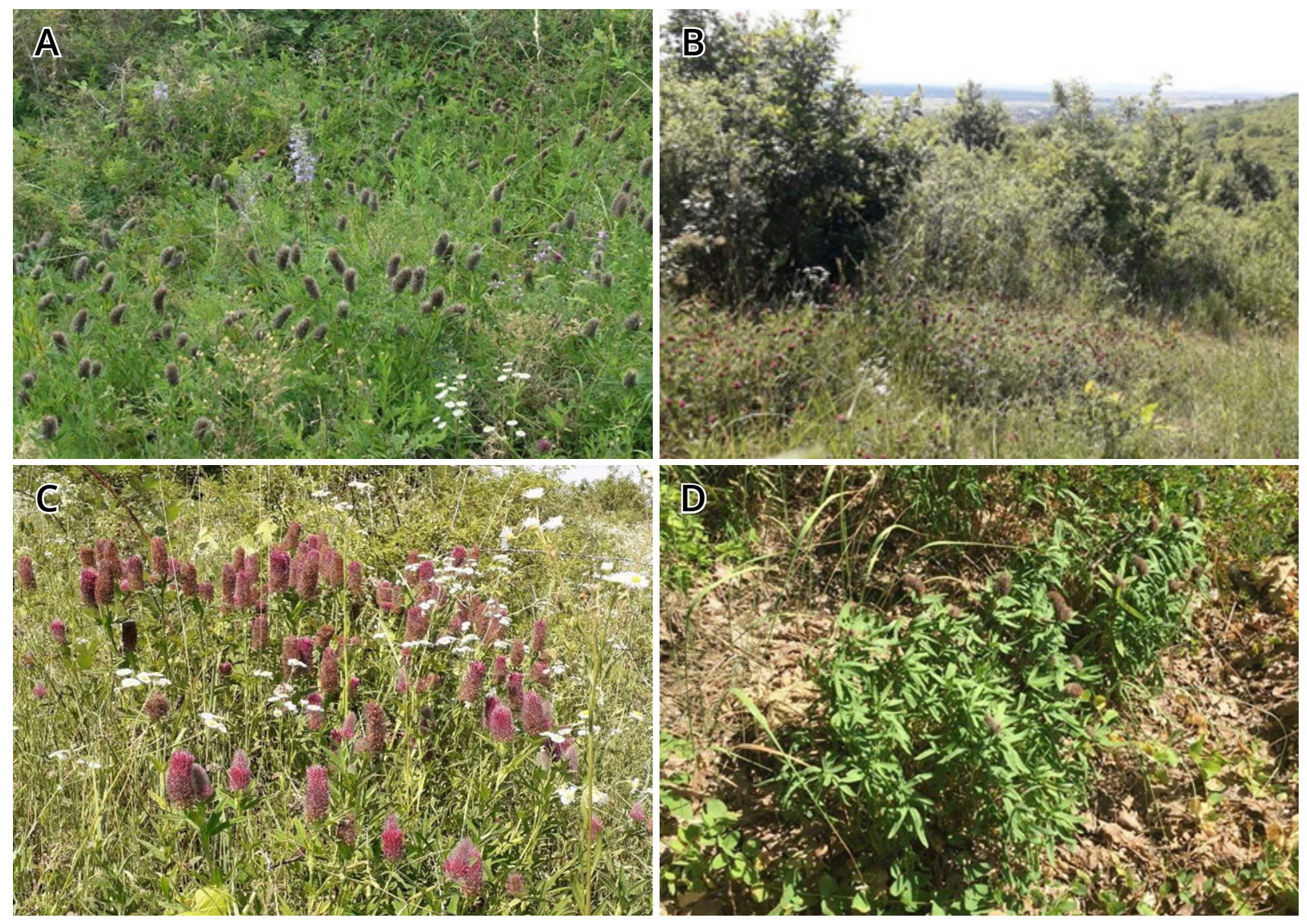

Figure 1. Trifolium rubens in Beregovo (A), Zatyshne (B), Muzhievo (C), and Mukachevo (D) populations.

Volyn region. Volodymyr-Volynskyi (Visjulina, 1954).

Zakarpattia region. Beregovo district: Beregovo, 15.06. 1947, Bilyk (UU), (Visjulina, 1954); 16.06.1953, Tovt, (UU); Beregovo, Zolota mountain, 16.06.1968, Chopyk (KW); Muzhiyivsk, 11.06.1957, Uliganets (UU); Bene, Chillagash Tetev mountain, 15.07.1960, Tovt (UU); Kuklabanya, 09.06.1948, Malynovskyi (LWS); Velykobereznyanskyi district: Maly Berezny, 07.07.1956, Khymynets(UU); Uzhok, Kinchyk mountain, 26.08.1955, Chopyk (KW); Maly Berezny, Dilok mountain, 25.06.1954, Rudenko, (UU); Vynohradiv district: Kholmovets, 12.06.1956, Chubirko (UU); Chopyk, 16.07.1963 (KWHA); Mukachevo district: Mukachevo, near the monastery 11.06.1947, Grin (KW), (Visjulina, 1954); Mukachevo vicinity, Lovachka mountain, (Margittai, 1911); 11.07.2018, Loya (KWHA); Mukachevo, Galish mountain, 21.05.2020, Loya (KWHA); Perechyn district: Plishka mountain, 04.08.1955 (Chopyk-KW); 09.07.1954, Tovt (UU); 05.06.1956, Tovt (UU); 03.08.1958, Tovt (UU); 25.07.1958, Simchera (UU); Sinatoria, 03.07.1956, Chopyk (KW); Rakhiv district: Dilove, Polonskaya, 03.07.1956, Tovt (UU); Rakhiv vicinity, Lysa Gora mountain, 26.06.1995, Kucheryava (KWU); Uzhhorod district: Kholmountainsi, 11.06.1947, Bilyk (KW); 06.03.1947, ? (UU), (Visjulina, 1954); 23.07.1958, Kovalenko (UU); 29.06.1956, Tovt (UU); 28.07.1987, Tasenkevych (LWS); Antalovetska Polyana mountain, 24.07.1958, Ilnytska (UU); Antalovtsi, 25.06.1955, Tovt (UU); Nevytsky castle, 24.07.1958, Zotyk (UU); Onokivtsi, 01.07.1968, Bartok (UU); Hlyboke, 08.07.1960, Karaeva (MW).
Ivano-Frankivsk region. Halytskyi district: Bovshev, Kasova Hora mountain, 13.7.1973, Kukovytsya; 49.226342, 24.696633, 23.06.2015, N. Sytschak (UkrBIN, 2021); 10.06.1969, Shelyag-Sosonko, Kukovytsya (KW), (Shumska \& Dmytrash, 2012); 08.06.2000, Kuzyarin (LWS); Tyaziv, 04.1960, Doroshenko (CHER); Rohatyn district: Velyki Goldy (Luchyntsi) (Shumska \& Dmytrash, 2012); Tysmenytsia district: Uzin, urochysche Zhdymyr (Shumska \& Dmytrash, 2012); Kolodiyivka, urochysche Pidgoroddya (Shumska \& Dmytrash, 2012); urochysche Simlin (Shumska \& Dmytrash, 2012); urochysche Hareva (Shumska \& Dmytrash, 2012); urochysche Gorozhanka (Shumska \& Dmytrash, 2012).

Lviv region. Lviv city, place Kryvchytsi (former village of Kryvchytsi), 07.1856, Łobarzewski (LWS); Lviv city, park Znesinnya, 49.847987, 24.076442, 20.07.2020, Voityk (UkrBIN, 2021); north-eastern vicinity of Lviv city, urochysche Khomets, 20.06.1986, Zelenchuk (LW); Brody district: Buchyna, Makitra mountain, 13.07.1997, Kuzyarin (LWS); 49.967495, 25.189118 (Batochenko, 2019); 50.035774 25.264379, 30.08.2019, Yurechko (Yurechko, 2020; UkrBIN, 2021); Ponykovytsya, Makitra mountain, 15.08.1954, Shelest (KWHA), 05.07.1987 (KW); Boratyn, Krugla mountain, 11.07.1987, Zelenchuk (LW, MW); 50.002236, 25.147742, 30.07.2019, Yurechko (Yurechko, 2020; UkrBIN, 2021); Vydra urochysche, 49.970372 25.180636, 04.08.2017, Yurechko (UkrBIN, 2021); Tetylkivtsi, 49.959404, 25.361032 (Batochenko, 2019); Verbivchyk, 49.893272, 25.283389 (Batochenko, 2019); Zolochiv district: Chervone, Lysa Gora mountain, 

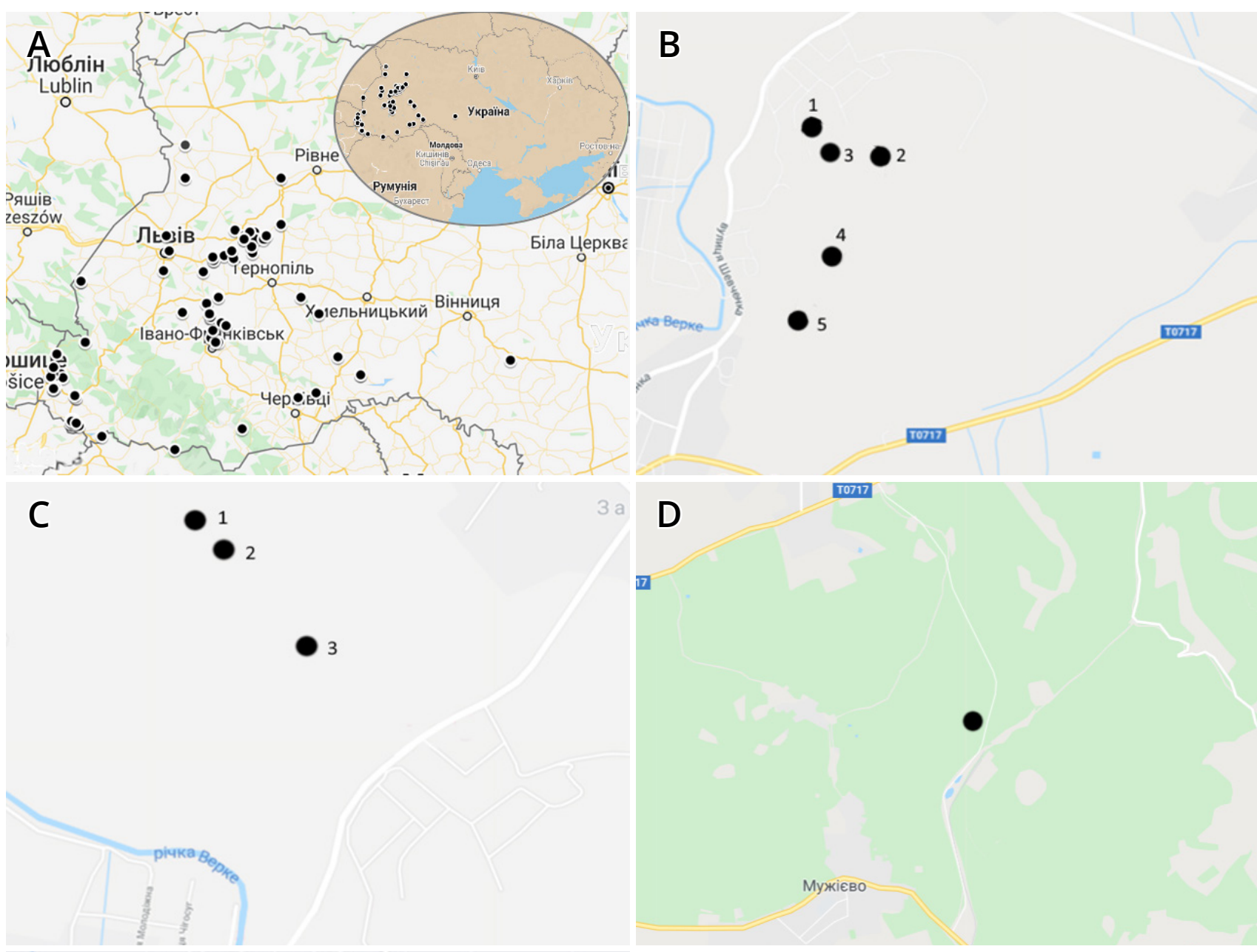

D

17

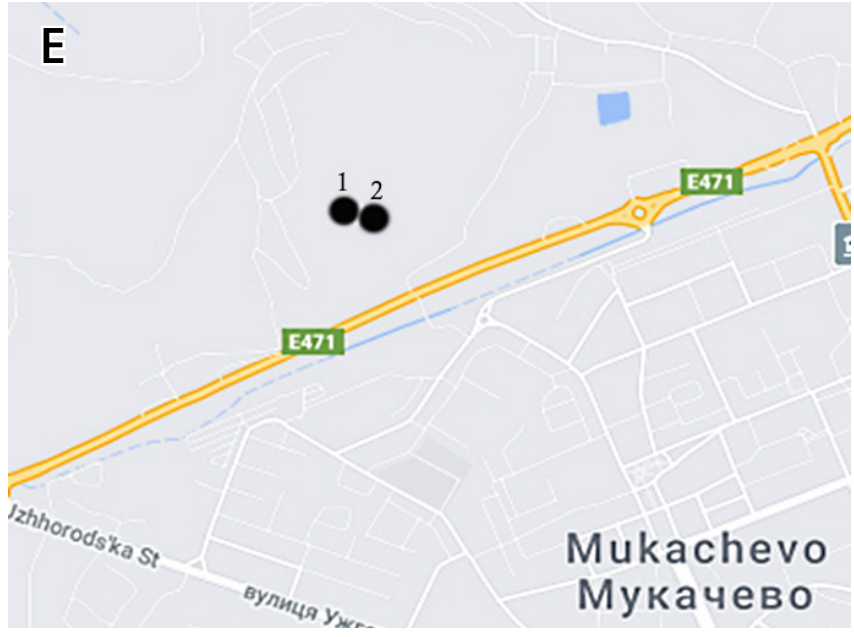

18.06.1956, Bukhalo (KW); 49.800963, 24.714529 (Batochenko, 2019); Tserkovna mountain, 07.07.1974, Shelyag-Sosonko, Kukovytsya, Didukh (KW); Stinka, 49.771803, 24.738519 (Batochenko, 2019); Khmelevo (Ralo, 2002); 19.07.1988, Iljinska (KW); Zolochiv, "nad Kraglem" 12.07.1938, Mądalski (LWS); Derevyanky urochysche, 49.824592, 25.062689, 10.07.2020, Yurechko (UkrBIN, 2021); Luka urochysche, 49.794502, 25.01998, 27.09.2017, Yurechko (Ralo \& Yurechko, 2019; UkrBIN, 2021); Zhovkva district: Mervychi, Kamin mountain, 30.06.1999, Kuzyarin (LWS); Zhydachiv district: Zhuravno, 1857, Łobarzewski (LWS); 29.07.1936, Mądalski (LWS); Peremyshlyany district: Borschiv, 16.07.1933, ?, (LWS); Pustomyty district: Derevach 06.1855; 1857, Łobarzewski

(LWS); Sokal district: ?, 1911, Szafer (LWS); Skomorokhy, 1869, Rehmann (LWS); Staryi Sambir district: Dobromyl, Meznetska mountain, 27.05.1967, Boyko (LWS).

Rivne region. Radyvyl district: Druzhba, 1859; 1858, Gomolinski (LWS); Berezne district: "Nadsluchanska Shveytsariya", the right bank of the river Sluch, Andriyenko (KW). Mlyniv district: Vladyslavivka, urochysche Hraboveshchyna (Didukh et al., 2010; Lohvynenko, 2012); Kurylykha, 50.562694, 25.7545 (Shtogryn et al., 2020). Shumsk district: 50.142583, 26.159583; 50.126444, 26.066889 (Shtogryn et al., 2020).

Ternopil region. Berezhany district: Kuryany, Holytsya mountain, 27.06.1976, Zaverukha (KW), (Yavorivskyi \&

Figure 2. General distribution of Trifolium rubens in Ukraine (A) and its investigated populations and Mukachevo (E). Numbers indicate the investigated fragments (loci). 
Stakhurska, 2017); Kremenets district: Pidlisne, urochysche Vakatsy, 20.07.2007, 18.06.2009, 24.07.2010, Hlinska (KWHA), 30.06.2014, Krytska, Novosad, Shcherbakova (KW-museum); Novosilky, 29.06.1958, Klokov (KW); Raslavka, 49.958393, 25.465275 (Batochenko, 2019); Maslyatyn mountain, 2006, Pronyuk, Oliyar (MNR); 50.137694, 26.092528 (Shtogryn et al., 2020); Pochayiv [?] (Visjulina, 1954); Zboriv district: Ratyshchi, Ratyska mountain, 1875, Schauer (LWS).

Khmelnytskyi region. Kamyanets-Podilskyi district: urochysche Sovyi Yar, 06.07.1949, Kuznetsova (KW), (Visjulina, 1954); Nizhyn, 13.07.1964, Krutskevych (KWHA); Sataniv (Visjulina, 1954).

Chernivtsi region. Khotyn district: Polyana, 26.06.1958, Kozak (CHER); Vyzhnytsa district: urochysche Velyki Luzhky, 15.07.1977, Shterma (CHER).

\section{Results and discussion}

\section{Distribution of Trifolium rubens in Ukraine}

Basing on the analysis of herbarium material and published data, we have confirmed that T. rubens is distributed only in the right-bank part of Ukraine (Fig. 2 A). It is registered from Vinnytsia, Zakarpattia, Ivano-Frankivsk, Lviv, Rivne, Ternopil, Khmelnytsky, and Chernivtsi regions. Although according to the Red Book of Ukraine (Didukh, 2009), T. rubens is not mentioned for the Khmelnytsky and Chernivtsi regions. Most locations are known from the Zakarpattia and Lviv regions. The current presence of T. rubens in the Volyn, Zhytomyr, Cherkasy, and Kyiv regions is doubtful and/or has no recent confirmation. For example, there is no recent confirmation of the presence of $T$. rubens in the Kyiv region. The herbarium voucher "Zhytomyr region. Novograd-Volynskyi district, village Mala Tsvilya, June 13, 2000, Orlov" deposited at the KW was re-identified by Y.P. Didukh as T. medium L., and we agree with that new identification. The report of T. rubens from Uman (Visyulina, 1954) was not confirmed too - there are no herbarium vouchers from this region yet.

\section{Populations of Trifolium rubens in Zakarpattia region}

In the investigated areas, the fragments of oak forests and shrubs occurred. The slopes were partially terraced and planted with vineyards, gardens or used as arable fields or pastures.
Population 1. The population of T. rubens in Beregovo (Figs. 1 \& 2) was confined to a plant community with rich floristic composition and mosaic structure. In this population, five fragments (loci) were studied (Table 1). The population was numerous, with about 300 plants. Monodominant fragments of the community were formed mainly by Calamagrostis, Trifolium, Coronilla, and Rubus species. Plants of T. rubens occurred on the slopes of the western and north-western exposures, and the relatively flat upper part of the hills. Some individuals grew on the northern slope among trees and shrubs, and some - along the trail. The herb layer was 30$60 \mathrm{~cm}$ high and has $80-90 \%$ of the projective cover. The shrub layer reaches up to $2 \mathrm{~m}$ high. Sometimes Quercus petraea Liebl., Populus tremula L., Castanea sativa Mill. overgrew between shrubs of Cornus sanguinea L., Prunus spinosa L., Chamaecytisus supinus (L.) Link, C. austriacus L., Rhamnus cathartica L., Rosa canina L. agg., and Rubus species (Table 2).

Shoots were concentrated in the groups (clumps) by $5-50$. Each clump occupied an area of about $0.5-2.0 \mathrm{~m}^{2}$. The average density of shoots was $28.4 \pm 1.3$ per $1 \mathrm{~m}^{2}$. In particular, $5.2 \pm 1.0$ per $1 \mathrm{~m}^{2}-$ for virginal shoots, $21.2 \pm 1.4$ per $1 \mathrm{~m}^{2}$ - for generative, $0.4 \pm 0.4$ per $1 \mathrm{~m}^{2}-$ for subsenile, and $3.6 \pm 1.0$ per $1 \mathrm{~m}^{2}$ - for senile. Like all others, this population was incomplete. Shoots in the generative state predominated (Table 1). There were also some separate generative plants at a distance 20-25 m from each other. Neither seedlings nor juvenile plants were found.

Plants were scattered irregularly on the territory. Occasionally, T. rubens plants co-dominated there together with Rubus fruticosus L. agg., Coronilla varia L., Lotus corniculatus L., and Clinopodium vulgare L.

According to the diagnostic species (Agrimonia eupatoria L., Campanula persicifolia L., Clinopodium vulgare, Geranium sanguineum L., Melampyrum nemorosum L., Origanum vulgare L., Peucedanum cervaria (L.) Lap., Trifolium medium, Vincetoxicum hirundinaria Medik., and others - see Table 2), communities with the participation of T. rubens should be attributed to the order Origanetalia Th. Müller 1962 class Trifolio-Geranietea sanguinei Th. Müller 1961 (Solomakha, 2008). 
Table 1. Characteristics of investigated Trifolium rubens populations.

\begin{tabular}{|c|c|c|c|c|c|}
\hline \multirow{2}{*}{ Population } & \multicolumn{5}{|c|}{ Number of shoots per $1 \mathrm{~m}^{2}$} \\
\hline & Virginal & Generative & Subsenile & Senile & Total \\
\hline \multicolumn{6}{|l|}{ 1. Beregovo } \\
\hline locus 1 & $4 \pm 0.5$ & $17 \pm 1.3$ & $5 \pm 1.2$ & 0.0 & 26 \\
\hline locus 2 & $6 \pm 0.9$ & $10 \pm 1.3$ & $4 \pm 1.1$ & $2 \pm 0.1$ & 22 \\
\hline locus 3 & $10 \pm 1.3$ & $45 \pm 1.5$ & $3 \pm 1.0$ & 0.0 & 58 \\
\hline locus 4 & $4 \pm 0.5$ & $16 \pm 1.3$ & 0.0 & 0.0 & 20 \\
\hline locus 5 & $2 \pm 0.1$ & $8 \pm 1.5$ & $6 \pm 1.0$ & 0.0 & 16 \\
\hline Mean \pm SD & $5.2 \pm 1.0$ & $19.2 \pm 1.4$ & $3.6 \pm 1.0$ & $0.4 \pm 0.4$ & $28.4 \pm 1.3$ \\
\hline Total (\%) & $26(18.3)$ & $96(67.6)$ & $18(12.7)$ & $2(1.4)$ & $142(100.0)$ \\
\hline \multicolumn{6}{|l|}{ 2. Zatyshne } \\
\hline locus 1 & $3 \pm 0.5$ & $9 \pm 1.5$ & $2 \pm 0.1$ & 0.0 & 14 \\
\hline locus 2 & $1 \pm 0.1$ & $26 \pm 1.4$ & $4 \pm 0.6$ & 0.0 & 31 \\
\hline locus 3 & 0.0 & $16 \pm 0.5$ & $1 \pm 0.1$ & 0.0 & 17 \\
\hline Mean \pm SD & $1.3 \pm 0.3$ & $17.0 \pm 1.7$ & $2.3 \pm 0.4$ & 0.0 & $20.6 \pm 0.6$ \\
\hline Total (\%) & $4(6.3)$ & $51(82.5)$ & $7(11.2)$ & $0(0.0)$ & $41(100.0)$ \\
\hline \multicolumn{6}{|l|}{ 3. Muzhieve } \\
\hline locus 1 & $13 \pm 0.0$ & $75 \pm 0.0$ & $3 \pm 0.0$ & 0.0 & 91 \\
\hline locus 2 & $8 \pm 0.0$ & $62 \pm 0.0$ & $4 \pm 0.0$ & 0.0 & 74 \\
\hline Mean \pm SD & $10.5 \pm 0.0$ & $68.5 \pm 0.0$ & $3.5 \pm 0.0$ & 0.0 & $82.5 \pm 0.0$ \\
\hline Total (\%) & $21(12.7)$ & $137(83.0)$ & $7(4.3)$ & $0(0.0)$ & $165(100.0)$ \\
\hline \multicolumn{6}{|c|}{ 4. Lovachka mountain } \\
\hline locus 1 & $13.1 \pm 0.4$ & $20 \pm 1.1$ & 0.0 & 0.0 & 33 \\
\hline locus 2 & $16.3 \pm 1.3$ & $11.1 \pm 0.9$ & 0.0 & 0.0 & 27 \\
\hline Mean \pm SD & $14.4 \pm 0.9$ & $15.6 \pm 1.0$ & 0.0 & 0.0 & $30.2 \pm 0.0$ \\
\hline Total (\%) & 29 (48.7) & $31(51.5)$ & $0(0.0)$ & $0(0.0)$ & $60(100.0)$ \\
\hline
\end{tabular}

Population 2. Near the village Zatyshne, T. rubens occurred on gentle slopes of southeastern and northern exposures with an inclination of about $20-30^{\circ}$ among shrubs, along paths, and, sometimes, in the 10-15-meter ecotone of the oak forest. A rich floral composition characterized this community due to the penetration of species from adjacent plant communities with the formation of mosaic complexes and due to the lack of shading. The community consisted of deciduous shrubs with significant participation of xerothermic species. The shrub layer was up to $2 \mathrm{~m}$ high. The herb layer's height was $30-60 \mathrm{~cm}$, and its projective cover reached $80-100 \%$. Calamagrostis epigejos (L.) Roth, C. arundinacea (L.) Roth, Trifolium rubens, T. medium, Melampyrum nemorosum, Clinopodium vulgare, Inula salicina L., and Vicia cracca L. predominated here (Table 2).

Plants of T. rubens were represented by small dense clumps $\left(1-3 \mathrm{~m}^{2}\right)$. In each clump were 2-8 generative individuals. An average density of shoots was 31 per $1 \mathrm{~m}^{2}$. In this population, only three loci were found with 41 shoots (Table 1).

Population 3. In T. rubens population near the village Muzhievo, two clumps formed by generative shoots were found. The population situated in the upper part of the gentle slope of the eastern exposure near thickets of shrubs with Robinia pseudoacacia L., Rosa canina agg., Rubus fruticosus agg., and Vitis vinifera $\mathrm{L}$. 
Table 2. Floristic composition of the plant communities in studied populations of Trifolium rubens.

\begin{tabular}{|c|c|c|c|c|}
\hline Population & 1 & 2 & 3 & 4 \\
\hline \multicolumn{5}{|l|}{ Tree layer } \\
\hline Castanea sativa Mill. & + & . & . & + \\
\hline Populus tremula L. & 1 & + & . & . \\
\hline Prunus avium (L.) L. & . & + & . & . \\
\hline Prunus cerasus L. & . & + & . & . \\
\hline Quercus petraea (Matt.) Liebl. & + & + & . & 1 \\
\hline Robinia pseudoacacia L. & . & . & + & + \\
\hline
\end{tabular}

Shrub layer

Cornus sanguinea L.

Prunus spinosa L.

Rhamnus cathartica L.

Rosa canina s.l.

Rubus fruticosus s.l.

Sambucus ebulus L.

Vítis vinifera L.

Herb layer

Achillea millefolium L.

Agrimonia eupatoria L.

Ajuga reptans L.

Allium oleraceum L.

Allium scorodoprasum L.

Anthericum ramosum L.

Artemisia absinthium L.

Astragalus glycyphyllos L.

Berteroa incana (L.) DC.

Betonica officinalis L.

Calamagrostis arundinacea (L.) Roth $1 \quad 2 \quad$.

Calamagrostis epigejos (L.) Roth $\quad \begin{array}{lllll}1 & 1 & 2 & 2\end{array}$

Campanula bononiensis L.

Campanula cervicaria L.

Campanula glomerata L.

Campanula persicifolia L.

Chamaecytisus austriacus (L.) Link

Chamaecytisus supinus (L.) Link

Clinopodium vulgare L.

Cota tinctoria (L.) J. Gay

Dactylis glomerata L.

Dianthus carthusianorum L.

Digitalis grandiflora Mill.

\begin{tabular}{l} 
Population \\
\hline Echium vulgare L. \\
Elymus repens (L.) Gould \\
Erigeron annuus (L.) Pers. \\
Euphorbia cyparissias L. \\
Festuca ovina L. \\
Festuca pratensis Huds
\end{tabular}

Filago arvensis L.

Fragaria vesca L.

Galatella linosyris (L.) Rchb.f.

Galium mollugo L.

Galium verum $\mathrm{L}$.

Genista tinctoria L.

Geranium sanguineum L.

Geum urbanum L.

Hypericum perforatum $\mathrm{L}$

Inula acuminate DC.

Lamium galeobdolon (L.) L.

Lathyrus niger (L.) Bernh.

Lathyrus pratensis L.

Lathyrus sylvestris L.

Lathyrus tuberosus L.

Leucanthemum vulgare Lam.

Lotus corniculatus L.

$\begin{array}{llll}1 & 2 & 3 & 4\end{array}$

Medicago falcata L.

Medicago lupulina L.

Melampyrum nemorosum L.

Melica transsilvanica Schur

Melilotus albus Medik.

Melilotus officinalis (L.) Lam.

Origanum vulgare L.

Pentanema germanicum (L.) D. Gut. Larr. et al.

Pentanema hirtum (L.) D. Gut. Larr. et al. Peucedanum cervaria (L.) Lap.

Plantago media L.

Potentilla inclinata Vill.

Potentilla recta $\mathrm{L}$.

Ranunculus acris L

Rumex confertus Willd.

\begin{tabular}{|c|c|c|c|}
\hline+ & . & . & . \\
\hline 1 & 1 & 1 & . \\
\hline 1 & 1 & 1 & + \\
\hline . & . & . & + \\
\hline+ & . & . & . \\
\hline . & . & + & . \\
\hline+ & . & . & . \\
\hline+ & . & . & . \\
\hline . & + & . & . \\
\hline+ & + & . & . \\
\hline+ & . & . & + \\
\hline+ & + & . & + \\
\hline+ & . & . & . \\
\hline+ & + & . & . \\
\hline+ & + & . & . \\
\hline+ & + & . & . \\
\hline+ & . & . & . \\
\hline . & . & . & 1 \\
\hline 1 & + & . & . \\
\hline+ & . & . & . \\
\hline+ & . & . & . \\
\hline . & 1 & . & . \\
\hline 2 & 2 & 1 & . \\
\hline · & . & . & . \\
\hline . & 1 & . & . \\
\hline+ & 1 & . & . \\
\hline+ & . & . & . \\
\hline+ & . & . & . \\
\hline . & + & . & . \\
\hline+ & 1 & . & + \\
\hline+ & . & . & + \\
\hline+ & . & . & . \\
\hline 1 & . & . & . \\
\hline & 1 & . & . \\
\hline+ & . & . & . \\
\hline & 1 & . & . \\
\hline+ & . & . & 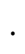 \\
\hline . & 1 & 1 & . \\
\hline
\end{tabular}


Table 2. Continued.

\begin{tabular}{|c|c|c|c|c|}
\hline Population & 1 & 2 & 3 & 4 \\
\hline Securigera varia (L.) Lassen & 2 & 2 & . & . \\
\hline Sedum maximum (L.) Suter & + & . & . & . \\
\hline Silene latifolia Poir. & + & . & . & . \\
\hline Stachys annua (L.) L. & + & 1 & . & . \\
\hline Symphytum officinale L. & . & + & . & . \\
\hline Tanacetum corymbosum (L.) Sch. Bip. & + & 1 & . & . \\
\hline Tanacetum vulgare L. & + & 1 & . & . \\
\hline Teucrium chamaedrys L. & . & + & . & . \\
\hline Torilis japonica (Houtt.) DC. & + & . & . & . \\
\hline Trifolium arvense L. & + & 1 & . & . \\
\hline Trifolium dubium Sibth. & 1 & . & . & . \\
\hline Trifolium medium L. & 1 & 2 & . & + \\
\hline Trifolium montanum L. & + & 1 & . & + \\
\hline Trifolium pannonicum Jacq. & . & + & . & . \\
\hline Trifolium pratense L. & + & . & . & . \\
\hline Trifolium repens $\mathrm{L}$. & . & 1 & . & . \\
\hline Trifolium rubens L. & 1 & 1 & 1 & 1 \\
\hline Verbascum lychnitis L. & 1 & . & . & . \\
\hline Veronica spicata L. & + & 1 & . & . \\
\hline Vicia cracca L. & 2 & 2 & 1 & . \\
\hline Vicia lathyroides L. & + & . & . & . \\
\hline Vicia villosa Roth & . & + & 1 & . \\
\hline Vincetoxicum hirundinaria Medik. & . & . & . & + \\
\hline Viola arvensis Murr. & + & . & . & . \\
\hline Viscaria vulgaris Röhl. & 1 & . & . & . \\
\hline
\end{tabular}

participation (Table 2). Lotus corniculatus, Calamagrostis epigeos, and Erigeron annuus (L.) Pers were co-dominants of the herb layer together with T. rubens. In this population, the smallest number of clumps and the highest density of shoots were registered. The clumps area did not exceed $1 \mathrm{~m}^{2}$.

Population 4. The population from the top of Lovachka mountain is located along the trail at the edge of the oak forest at the $295 \mathrm{~m}$ a.s.l. on a slope with an inclination of about $30^{\circ}$. The tree layer formed by Quercus petraea (Matt.) Liebl., Robinia pseudoacacia, and Castanea sativa. Calamagrostis epigejos, Dactylis L., Trifolium rubens, Clinopodium vulgare, and

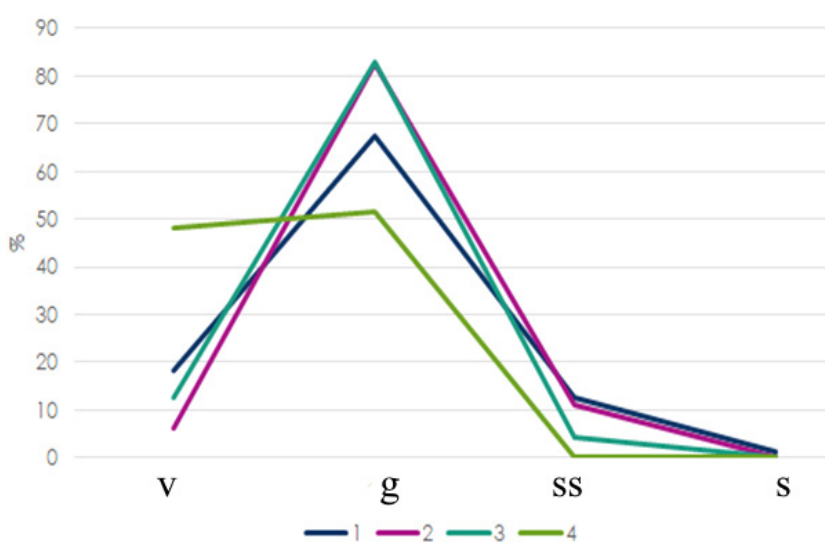

Figure 3. The ontogenetic spectrum of Trifolium rubens populations. 1-4 -populations' numbers; v - virginal, g - generative, ss - subsenile, and $\mathrm{s}$ - senile shoots.

Lathyrus niger (L.) Bernh dominated in the herb layer, the projective cover of which reached about $50 \%$. Two loci of this population were studied. Only generative and virginal shoots were found in clumps. Totally, 145 shoots were recorded in this population. The average density was $28.4 \pm 5.0$ shoots per $1 \mathrm{~m}^{2}$; in particular, $27 \pm 3.6$ vegetative and $26.8 \pm 2.9$ generative shoots per $1 \mathrm{~m}^{2}$. Neither senile nor subsenile shoots were detected.

Hence, the density of virginal shoots in the studied populations varied from 1 to 8 per $1 \mathrm{~m}^{2}$. The most abundant were generative shoots (17-68 per $1 \mathrm{~m}^{2}$ on average). The number of subsenile shoots was $0-3$ per $1 \mathrm{~m}^{2}$, and senile - 0-2 per $1 \mathrm{~m}^{2}$ (Fig. 3). The total number of shoots in the studied loci ranged from 41 to 165 per $1 \mathrm{~m}^{2}$.

\section{Conclusions}

Trifolium rubens is distributed only in the right-bank part of Ukraine. There are 78 confirmed localities of this species in Ukraine. The presence of T. rubens in Volyn, Zhytomyr, Cherkasy and Kyiv regions is doubtful and has no recent confirmations.

Studied populations in Zakarpattia region were associated with meadow-steppe areas with the participation of shrubs. They were often located on slopes and associated with xerophile semi-natural shrub communities in areas with anthropogenic impact. They were often situated along pathways, on forest 
edges, and associated with ecotones between forest or shrubs and herb communities from the class Trifolio-Geranietea sanguinei. In studied localities, T. rubens participated in communities with Rubus fruticosus agg., Coronilla varia, Lotus corniculatus, Clinopodium vulgare, Trifolium medium, Melampyrum nemorosum, Inula salicina, Vicia cracca, and Calamagrostis species.

Apparently, metapopulational structure with the dispersed disposition of plants on the large areas is characteristic for the T. rubens populations. The distances between loci in populations varied from 10 to $100 \mathrm{~m}$. All studied populations were incomplete with the advantage of generative shoots (17-68 shoots per $1 \mathrm{~m}^{2}$ or $51.7-82.5 \%$ from the total number of shoots). The absence of senile shoots evidences normal populations' conditions.

\section{References}

Batochenko, V. M. (2019). Findings of some flora's species listed in the Red Book of Ukraine in Volyno-Podilia and Zakarpattia. In A. A. Kuzemko (Ed.), Records of plants and fungi of the Red Book and the Berne Convention (Resolution 6). Vol. 1 (pp. 24-39). DrukArt. (In Ukrainian)

Braun-Blanquet, J. (1964). Pflanzensoziologie. Grundzüge der Vegetationskunde. Springer. https:// doi.org/10.1007/978-3-7091-8110-2

Didukh, Y. P. (2009). Konyushyna chervonuvata - Trifolium rubens L. In Y. P. Didukh (Ed.), Red Book of Ukraine. The Plant Kingdom (p. 484). Globalconsulting. (In Ukrainian)

Didukh, Y.P., Vasheniak, Y. A., \& Fedoronchuk, M. M. (2010). New localities of rare plant species in the central part of Podillya and adjacent regions. Ukrainian Botanical Journal, 67(1). 93-99. (In Ukrainian)

Dmytrash, I. (2015). Eco-coenotical groups of rare species of Southern Opillya flora. In Proceedings of XII International Scientific Conference of Young Scientists (pp. 35 - 38). (In Ukrainian)

Dmytrash-Vatseba, I. I., \& Shumska, N. V. (2016). Findings of rare species of vascular plants in the territory of Bystrytsa-Tlumach Opillya. In Proceedings of IV International Scientific Conference "Rare Plants and Fungi of Ukraine" (pp. 70-75). (In Ukrainian)

Dubyna, D. V., Dziuba, T. P., lemelianova, S. M., Bagrikova, N. O., Borysova, O. V., Borsukevych, L. M., Vynokurov, D. S.,
Gapon, S. V., Gapon, Y. V., Davydov, D. A., Dvoreczkyj, T. V. Didukh, Y. P., Zhmud, O. I., Kozyr, M. S., Konishhuk, V. V., Kuzemko, A. A. Pashkevych, N. A., Ryff, L. E., Solomakha, V. A., ... Yakushenko, D. M. (2019). Prodrome of the vegetation of Ukraine. Naukova Dumka. (In Ukrainian)

Gnatiuk, A. M., Gaponenko, M. B., Loya, V. V., \& Gaponenko A. M. (2020). Peculiarities of Trifolium rubens L. populations research in natural phytocenoses. In Proceedings of the International Scientific conference "Problems of avoiding biodiversity loss of the Ukrainian Carpathians" (pp. 25-28). (In Ukrainian)

Kagalo, A. A., Tsaryk, Y. V., Skibitska, N. V., Danylyk, I. M., Sytschak, N. M., Bednarska, I. O., \& Doroshenko, K. V. (2012). Proposals to the monitoring method of populations of plant species included in the Red Data Book of Ukraine. Proceedings of Precarpathian National University. Ser. Biology, 17, 3-8. (In Ukrainian)

Konishchuk, V., Batochenko. V., \& Pankovska, G. (2017). Phytososological analysis of hydroecosystems of the NNP "North Podillya". Agroecological Journal, 4, 87-94. (In Ukrainian)

Lohvynenko, I. P. (2012). Modern state of rare species populations of steppe groups of Volyn Upland. Plant Introduction, 55, 9-14. (In Ukrainian). https://doi.org/10.5281/zenodo.2541582

Margittai, A. (1911). Adatok Bereg vármegye flórájához. Magyar Botanikai Lapok, 10, 388-413.

Matuszkiewicz, W. (2001). Przewodnik do oznaczania zbiorowisk roślinnych Polski. Wydawnictwo naukowe PWN.

Meusel, H., \&Jäger, E.J. (1992). Vergleichende Chorologie der Zentraleuropäischen Flora. Bd. III. Fischer Verlag

Onyshchenko, V. A., \& Andrienko, T. L. (Eds.). (2012). Phytodiversity of nature reserves and national nature parks of Ukraine. Part 1. Biosphere reserves. Nature reserves. Phytosociocentre. (In Ukrainian)

PoWO. (2021, January 25). Plant of the World Online. https://powo.science.kew.org/

Ralo, V. M. (2002). The location of rare plant species on Voronyaki (North-Western Podolia region). Scientific Principles of Biodiversity Conservation, 4, 95-102. (In Ukrainian)

Ralo, V. M., \& Yurechko, R. Y. (2019). Findings of the plants from the Red Book of Ukraine in frames of NNP "Pivnichne Podilia". In A. A. Kuzemko (Ed.), Records of plants and fungi of the Red Book and the Berne Convention (Resolution 6). Vol. 1 (pp. 325328). DrukArt. (In Ukrainian)

Rašomavičius, V. (Ed.). (2007). Lietuvos raudonoji knyga. Lututè.

Ružičková, H., Halada, L., Jedlička, L., \& 
Kalivodová, E. (Eds.). (1996). Biotopy Slovenska - príručka k mapovaniu a katalóg biotopov. Ústav Krajinnej Ekológie SAV.

Shtogryn, M. O., Shtogun, A. O., \& Bobryk, I. V. (2020). Findings of the plants listed in the Red Book of Ukraine on the territory of the National Nature Park "Kremenetski Gory" and adjacent areas. In A. A. Kuzemko, S. S. Sadohurska, P. Y. Gol'din, V. V. Kavurka, Y. K. Kutsokon, O. D. Nekrasova, O. V. Vasyliuk, O. V. Prylutskyi, \& M. Y. Rusin (Eds.), Records of protected animal, plant and fungi species in Ukraine (pp. 650-654). Tvory. (In Ukrainian)

Shumska, N. V., \& Dmytrash, I. I. (2012). The distribution of rare species of vascular plants included in the "Red Book of Ukraine" in the Galytsky National Nature Park and adjacent territories. In Proceedings of the international conference "Flora in the Red Book of Ukraine: implementation of the Global Strategy for Plant Conservation" (pp. 316-320). (In Ukrainian)

Solomakha, V. A. (2008). Syntaxonomy of vegetation of Ukraine. The third approximation. Phytosociocentre. (In Ukrainian)

Thiers, B. (2016). Index Herbariorum. A global directory of public herbaria and associated staff. New York Botanical Garden's Virtual Herbarium. http://sweetgum.nybg.org/science/ih/
UkrBIN. (2021, 7 April). Ukrainian Biodiversity Information Network (public project \& web application). http://www.ukrbin.com

Visjulina, O. D. (1954). Genus 455. Koniushyna - Trifolium. In: D. K. Zerov (Ed.), Flora of UkrSSR. Vol. 6 (pp. 381-419). Publishing house of the AS of UkrSSR. (In Ukrainian)

Yavorivskyi, R. L., \& Stakhurska, M. V. (2017). Species composition of the Fabaceae L. family in the flora of the Berezhany district of the Ternopil region. In Proceedings of the VIII All-Ukrainian scientific-practical conference with international participation "Biological Studies-2017" (pp. 45-46). (In Ukrainian)

Yurechko, R. Y. (2020). Plants and fungi from the Red Book of Ukraine on the territory of the NNP "Pivnichne Podilia" (Lviv region) and its outskirts. In A. A. Kuzemko, S. S. Sadohurska, P. Y. Gol'din, V. V. Kavurka, Y. K. Kutsokon, O. D. Nekrasova, O. V. Vasyliuk, O. V. Prylutskyi, \& M. Y. Rusin (Eds.), Records of protected animal, plant and fungi species in Ukraine (pp. 657-679). Tvory. (In Ukrainian)

\section{Поширення Trifolium rubens в Україні та сучасний стан популяцій у Закарпатській області}

Алла Гнатюк ${ }^{1, ~ *, ~ М и к о л а ~ Г а п о н е н к о ~}{ }^{1}$, Власта Лоя ${ }^{1}$, Андрій Гапоненко ${ }^{2}$

\footnotetext{
${ }^{1}$ Національний ботанічний сад імені М.М. Гришка НАН України, вул. Тимірязєвська, 1, Київ, 01014, Україна; gnatiukalla@gmail.com

2 Національний університет біоресурсів і природокористування України, вул. Героїв оборони, 15, корпус 4, Київ, 03041, Україна
}

Trifolium rubens - це центральноєвропейський лісостеповий вид рослин, який в Україні знаходиться на східній межі поширення і включений до Червоної книги України (2009).

Дослідження проводили протягом 2016-2020 років. Метою дослідження було проаналізувати поширення цього виду в Україні, описати умови місцезростань та оцінити сучасний стан його популяцій у Закарпатській області. Для вивчення поширення виду було використано результати польових досліджень, дані з літературних та онлайн джерел, а також відомості з гербаріїв. Загалом було проаналізовано 78 місцезнаходжень T. rubens в Україні. В результаті чого було встановлено, що T. rubens трапляється в Закарпатській, Львівській, Івано-Франківській, Тернопільській, Хмельницькій, Рівненській, Чернівецькій та Вінницькій областях. Дві з цих областей (Хмельницька і Чернівецька) не наводилися ранішеу Червоній книзі України. Присутність природнихпопуляцій T. rubensу Волинській, Житомирській, Черкаській та Київській областях $є$ сумнівним і не має сучасного підтвердження. Найбільше місцезнаходжень цього виду відомо з Закарпатської та Львівської областей. 
Виявлено три нові місцезнаходження T. rubens у Вулканічних Карпатах та їхньому передгір'ї. Зокрема, описано флористичний склад фітоценозів та оцінено онтогенетичний стан популяцій у Берегівському та Мукачівському районах Закарпатської області. Ці популяції ізольовані 3 дисперсним розташуванням особин на великих площах. Trifolium rubens трапляється тут на лучностепових і лучних ділянках, на схилах пагорбів, а також у складі мезоксерофільних вторинних (напівприродних) чагарникових угрупованнь на антропогенно трансформованих ділянках. Часто популяції цього виду розташовані вздовж стежок, на узліссях, перелогах у формаціях класу TrifolioGeranietea sanguinei. Усі досліджені популяції неповностанові з переважанням генеративних пагонів.

Ключові слова: Trifolium rubens, хорологія, популяції, Україна 